omhandler insekter, gir en god introduksjon til de respektive fagområder. Målgruppen er primært bachelor- og mastergradsstudenter i biologi eller veterinærmedisin som ønsker en introduksjon til rettsmedisinsk biologi. Og for denne gruppen kan dette være en nyttig lærebok.

For leger, rettsgenetikere og rettspatologer vil det være andre bøker og oppslagsverker som er mer sentrale. Boken kan imidlertid være av verdi som et supplement til øvrig litteratur nettopp fordi den har en slik bred introduksjon til ulike emner.

\section{Rune Andreassen}

Avdeling for helsefag

Høyskolen i Oslo

\section{Viktig om behovet for forebygging av barneulykker}

Peden M, Oyegbite K, Ozanne-Smith J et al, red. World report on child injury prevention 228 s, tab, ill. Genève: WHO, 2008. Pris CHF 40 ISBN 978-92-4-156357-4

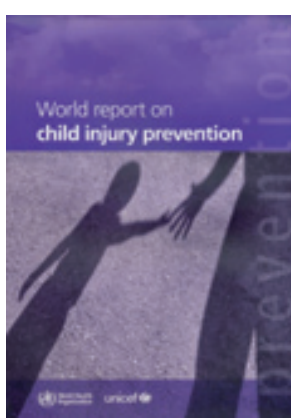

Dette er en velskrevet bok i paperbackformat, med oversiktlige tabeller og figurer. Leseren får en viktig påminnelse om at globalt dør hvert år opp mot en million barn under 18 år av ulykker. Og viktigst, disse hendelsene kan i stor grad forebygges. I tillegg til disse dødstallene kommer titalls millioner barn som må leve med senfølger av sine skader. Trafikkulykker, drukning, brannskader, fall og forgiftninger er i rangert rekkefølge de fem hyppigste ulykkestyper. Det gis en god dokumentasjon av den sosioøkonomiske gradient som gjelder for denne uhelsen, både inter- og intranasjonalt. Over $95 \%$ av disse dødsfallene skjer i land med lav eller midlere inntekt. Men også i rike land er ulykker årsak til $40 \%$ av barnedødeligheten. I 2003 var ulykker den fremste årsaken til tapte leveår i Norge i aldersgruppen 1-44 år. Trafikkulykker, drukning, brann, kvelning og fall var de hyppigste fem ulykkestyper i rangert orden for aldersgruppen under 25 år (1).

De forebyggende strategier er beskrevet på bakgrunn av forskningsbasert erkjennelse og omhandler: lover/forskrifter og håndhevelse av disse, modifisering av produkter, bygging av sikre fysiske miljøer, hjemmebesøk og promovering av sikkerhetsprodukter (for eksempel skåldingsvern påmontert komfyren). I tillegg anbefales opplysningsarbeid og ferdighetstrening.
Opplysning som enkeltstående virkemiddel har stor historisk, men liten forskningsmessig begrunnelse. Imidlertid er opplysningskampanjer effektive når de integreres i orkestrerte multidisiplinære og tverrfaglige forebyggende programmer. WHO har lansert «Safe Community» (Trygge lokalsamfunn) (2) som benytter denne samarbeidsmodellen. Den innbefatter en koalisjon av offentlige og private aktører og benyttes foreløpig i Norge i bare 17 av landets 430 kommuner.

Boken gir et godt faktagrunnlag for den som er engasjert i forebygging av skader. Den anbefales for alle som er interessert i dette temaet. Spesielt vil den være nyttig for medisinstudenter og leger som er opptatt av samfunnsmedisin. Våren 2009 skal den nye strategiplanen for skadeforebygging i Norge behandles politisk. Boken burde derfor også ligge på bordet til sentrale beslutningstakere som planlegger den nye helsereformen og gir varsler om at legene skal ta større samfunnsmedisinsk ansvar enn dagens ordning med fastleger gir rom for. Den bør ligge godt synlig, slik at forebygging av ulykker får den plass i reformen som er i samsvar med omfanget av den uhelse barneulykker representerer.

\section{Børge Ytterstad}

Institutt for samfunnsmedisin

Universitetet i Tromsø

\section{Litteratur}

1. Statistisk sentralbyrå. Statistikkbanken. http:// statbank.ssb.no/statistikkbanken (14.4.2004).

2. Ytterstad B. Verdien av skadeforebygging i Norge etter «Safe Community» - modellen i Harstad. Tidsskr Nor Lægeforen 1999; 119: 68-70.

\section{Stor lærebok i transfusjonsmedisin}

Simon T, Snyder EL, Solheim BG et al, red. Rossi's Principles of transfusion medicine 4. utg. 1112 s, tab, ill. Chichester: WileyBlackwell, 2009. Pris GBP 150 ISBN 978-1-4051-7588-3

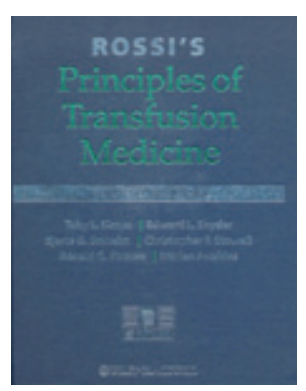

Verdens sannsynligvis største lærebok i transfusjonsmedisin foreligger nå i revidert utgave, sju år etter den forrige. Forfatterne har som ambisjon å skape den beste faglige referansetekst for alle som arbeider med transfusjon, enten hos pasienten eller i den klinikknære blodbanken.

Hele 114 forfattere har bidratt, hvorav 85 fra USA og seks fra Canada. Boken er utarbeidet primært for amerikanske forhold og gis ut i samarbeid med American Association of Blood Banks. Redaktørene angir imidlertid at de har ønsket å tilpasse denne utgaven mer til internasjonale perspektiver enn før. En av redaktørene er norsk.

Stoffet presenteres i seks seksjoner og 66 kapitler. Seksjonene omfatter fremstilling og alminnelig bruk av blodkomponenter, kliniske indikasjoner relatert til fagområder, aferese som blodkilde og behandlingsform, farer og bivirkninger ved transfusjon, samt celleterapi. Både basale og kliniske aspekter får god plass. Innholdet dekker derfor det meste av det transfusjonsmedisinske fagområdet. Man kunne ønsket seg en mer omfattende drøfting av globale, ressursmessige og etiske aspekter ved transfusjon. Amerikansk lov- og regelverk drøftes derimot grundig i et eget kapittel.

Fremstillingen er gjennomgående klar og lettlest. Det stikkes ikke under stol at kunnskapsnivået i transfusjonsmedisin ofte ikke er tilfredsstillende, og det gis gode drøftinger av kontroversielle forhold, som f.eks. den kliniske betydningen av endringer i erytrocytter ved lagring i blodbank. Amerikanernes konfliktfylte forhold til leukocyttfiltrering av blodprodukter behandles $i$ et eget kapitel. Antallet referanser er meget stort.

Hemolytisk sykdom hos foster og nyfødt behandles $i$ et nyskrevet og kompakt kapittel. Omtalen av programmer for antenatal diagnostikk og oppfølging ved immunisering er svært summarisk. Teksten om føtal og neonatal alloimmun trombocytopeni er dessverre spredt på flere steder, og neonatal alloimmun granulocytopeni omtales meget kortfattet. Ved neste revisjon vil man ønske seg en samlet og bredere gjennomgang av mor-barn-immunologiske tilstander og profylakse og behandlingsformer ved slike.

Det er mye tekst og den er relativt sparsomt illustrert. Alle illustrasjoner er i svarthvitt. Skriften er ganske grå og mindre enn i forrige utgave. Boken er derfor ikke spesielt fristende å lese. Mange kapitler ville ha tjent på at man hadde kondensert teksten. Dette kompenseres delvis med gode resymeer etter hvert kapittel.

Med disse forbeholdene anbefales boken til alle som ønsker å sette seg grundig inn i sentrale aspekter ved moderne transfusjonsmedisin. Den er også med på å gi identitet til et ungt fagområde som ofte glemmes i den store sammenhengen, til tross for at det er av grunnleggende betydning for det somatiske helsevesenet.

Hans Erik Heier

Avdeling for immunologi og transfusjonsmedisin Oslo universitetssykehus, Ullevål 